Annals of Warsaw University of Life Sciences - SGGW

Horticulture and Landscape Architecture No 39, 2018: 95-104

(Ann. Warsaw Univ. of Life Sci. - SGGW, Horticult. Landsc. Architect. 39, 2018)

DOI 10.22630/AHLA.2018.39.9

\title{
Principles of the tree risk management plan in Poland
}

EDYTA ROSŁON-SZERYŃSKA, AGNIESZKA GAWŁOWSKA

Faculty of Horticulture, Biotechnology and Landscape Architecture, Warsaw University of Life Sciences - SGGW

\begin{abstract}
Principles of the tree risk management plan in Poland. Trees are important and provide us with many benefits on which we rely. Trees can, however, pose a risk to people and property. It is important that we assess their risk to protect public safety. The overall goal of a community tree risk management program is to reduce the risk of injury and damage to people and property to levels that are considered acceptable in accordance with city policies and practices. Initiating a tree risk management program is an important step in developing effective tree management programs, and community tree populations. Tree-related risk management systems are developing rapidly, especially in Germany and in the United States. The aim of this study is to diagnose how trees are evaluated and managed in Poland. The research was carried out in the form of an electronic survey containing 25 closed and open questions. The replies were obtained from 422 respondents of municipalities across the country (city municipalities $(\mathrm{CM})-15.9 \%$ of all respondents, urban-rural communes (URC) $-25.6 \%$ of the total, and rural communities (RC) $-58.5 \%$ of all respondents). The results show that there is lack of standards and procedures associated with tree risk management in our country. It is necessary to develop the tree management system on the basis of the following conditions. The standards and criteria of the tree management system should be identified in the program of environmental protection or other strategic documents for municipalities, implemented pursuant to resolutions and ordinances. It should be applied as standard, multitask and multipurpose risk management procedures. The inspection of trees should be conducted based on objective methods. It is extremely important to monitor the risk (collecting statistics of accidents).
\end{abstract}

Key words: tree management, tree hazards, tree assessment, tree risk management

\section{INTRODUCTION}

Trees are an important part of the urban landscape. They provide us with many benefits on which we rely. Their significance has been described in many scientific papers (Szczepanowska 2001). Trees can, however, pose a risk to people and property. It is important that we assess their risk to protect public safety. The city manager must balance this risk with the aesthetic, ecological, environmental and social benefits that trees bring. Controlling tree failures and tree risk are primary objectives for arborists and urban tree managers.

Commonly, in routine assessments of urban trees visual methods are applied. The first methods of urban tree assessments were developed in the 1970s in Germany and the USA (Rosłon-Szeryńska 2013). The risk assessment has received considerable attention in the last decade. The overall goal of a community tree risk management program is to reduce the risk of injury and damage to people and property to levels that are considered acceptable in accordance with city policies and practices. Initiat- 
ing a tree risk management program is an important step in developing effective tree management programs and community tree populations (Coder 1996, Rosłon-Szeryńska 2013).

In England, The National Tree Safety Group (NTSG) was convened in 2007 to develop a nationally-recognised approach to tree safety management and to provide guidance that is proportionate to the actual risks from trees. The NTSG released its guidance "Common Sense Risk Management of Trees" in December 2011. The NTSG have identified that the overall estimated risk of death per year from fallen trees and branches in the UK is extremely low: about 1 in 10 million, whereas the annual risk of death in a road accident is about 1 in 16,800 (NTSG, 2011).

In the United States, The International Society of Arboriculture (ISA) and other industry entities worked to create the first American National Standards Institute (ANSI) standard for tree risk assessment (ANSI A300 Standard, Part 9 - Tree Risk Assessment) in 2011. Coinciding with the release of the standard was the publication of ISA's Tree Risk Assessment Best Management Practices (BMP) - a notable departure from the preceding ISA risk assessment method developed by Matheny and Clark (1994). In 2013 ISA initiated its first qualification - the Tree Risk Assessment Qualification (TRAQ) - adapted from the ISA Pacific Northwest Chapter's TRACE program and the tree risk assessment BMP (Koeser et al. 2016).

In Germany, urban tree inspections include a safety assessment as determined by the tree inspection policy (Baumkontrollrichtlinie) and the inspec- tors responsible for tree maintenance are certified by Germany's association of landscape experts (Forschungsgesellschaft Landschaftsentwicklung Landschaftsbau, FLL). Tree assessment and risk assessment standards are described in ÖNORM L1122 Kontrolle/Pflege, 2003/11 (Rosłon-Szeryńska 2014).

According to Rosłon-Szeryńska (2013), there are no standards and procedures related to Tree Risk Management in Poland. The lack of detailed knowledge on accident risk and the reasons behind impaired tree stability leads to generalisations. Accident risk is also rarely estimated and tree assessment is therefore limited to examining its stability using more or less subjective methods. Trees are assessed only occasionally, mostly in the investment process or upon the application of the land owner.

The aim of this study is to diagnose how trees are evaluated and managed in Poland. This study will discuss how to develop in our country a tree risk management program, criteria important for assessing tree risks, and ways to prevent and minimise future tree risks.

\section{MATERIAL AND METHODS}

The risk management follows a certain scheme. One of them is showed by the ISO 31000 standard from 2009. This standard includes the stages of the risk management process (identification, estimation, assessment, response and monitoring), and stages of creating the risk management structure. This chapter presents the results of a survey concerning the conditions and methods of tree monitoring by local government units 
(JST) in Poland. The problem has been assessed with relation to the risk management scheme according to the ISO 31000 standard. The scheme includes 4 essential elements: multidimensional planning and risk identification; monitoring and risk assessment; risk treatment; communication and consultation (Fig. 1).

\section{RESULTS AND DISCUSSION}

First, planning activities and risk identification in Poland were assessed. The constructed survey showed a lack of comprehensive procedures concerning the risk management. Individual fragments of this process are being imple-

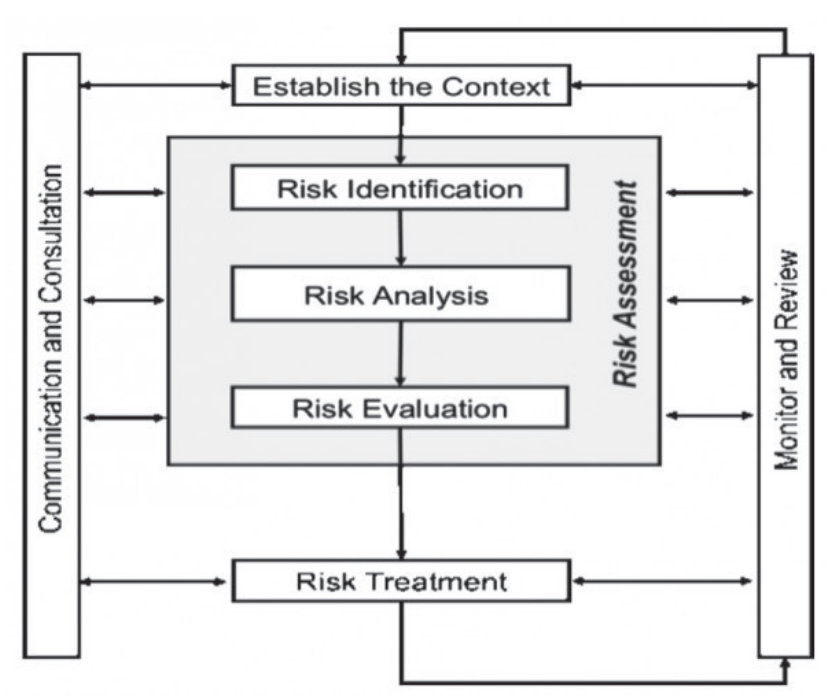

FIGURE 1. Risk management scheme according to ISO 31000 standard

The research was carried out in the form of an electronic survey containing 25 closed and open questions. The replies were obtained from 422 respondents of municipalities across the country. The percentage share of respective types of municipalities looks as follows: city municipalities (CM) 67 replies, which constitutes $15.9 \%$ of all respondents, urban-rural communes (URC) $108-25.6 \%$ of the total, and rural communities (RC) $247-58.5 \%$ of the total (Parlińska 2016). The results were tabulated using descriptive statistics. The numerical data are presented using a graphical display - histograms. mented. This action is often carried out intuitively. One of the main problems is the lack of inventoried tree resources by the municipalities. If we asked, "How many trees are located in your area?", then more than a half of the community administrators did not know the answer. The administrators of rural as well as urban municipalities don't have much knowledge about the afforestation resources of their area. As many as $58.2 \%$ of urban communes didn't give their reply concerning this issue, justifying this with the lack of comprehensive inventories. 
Almost a half of the responders (city municipalities - 41.8\%, urban - rural communes $-42.4 \%$, rural communities $-44.1 \%$ ) gave the same answer to the question "How often are the tree inventories carried out within the individual area?". They said that no comprehensive tree inventory on their territory had been conducted. What is worrying is the low percentage of tree inventories, which are carried out "once a year" (CM - 7.5\%; $\mathrm{URC}-8.3 \%$; RC $-6.9 \%$ ) and "once per $2-3$ years" (CM - 7.5\%; URC - 3\%; RC $-3.1 \%$ ) - Figure 2.

There was a question in the survey about the qualifications of the people preparing tree assessments. The study shows that the assessment is being conducted in one step. The evaluation of trees mainly is being taken by office workers (60-80\% of municipalities). However, in special cases the assessment is being conducted in 2 steps (with an expert) or contracted out to an outsourcing specialised company. In response to the question "What education have persons/companies implementing the inventory?", the respondents gave the following answers: The percentage of persons performing inventories with the titles of landscape architect in city municipalities is $30.4 \%$, in urban-rural communes $-31.6 \%$ and in rural communities $-30.6 \%$. Persons with an administration and management education are mostly conducting the inspection of trees in rural communities $(28.5 \%)$, and in urban-rural and city municipalities $12 \%$. On average every fifth person conducting tree assessments has the following education: agricultural, construction, environmental engineering and geodesy (CM 19.6\%; URC 20.3\%; RC 19.0\%) - Figure 3.

For the question "Whether an inventory is always done by the same person/ /company?" respondents replied in the

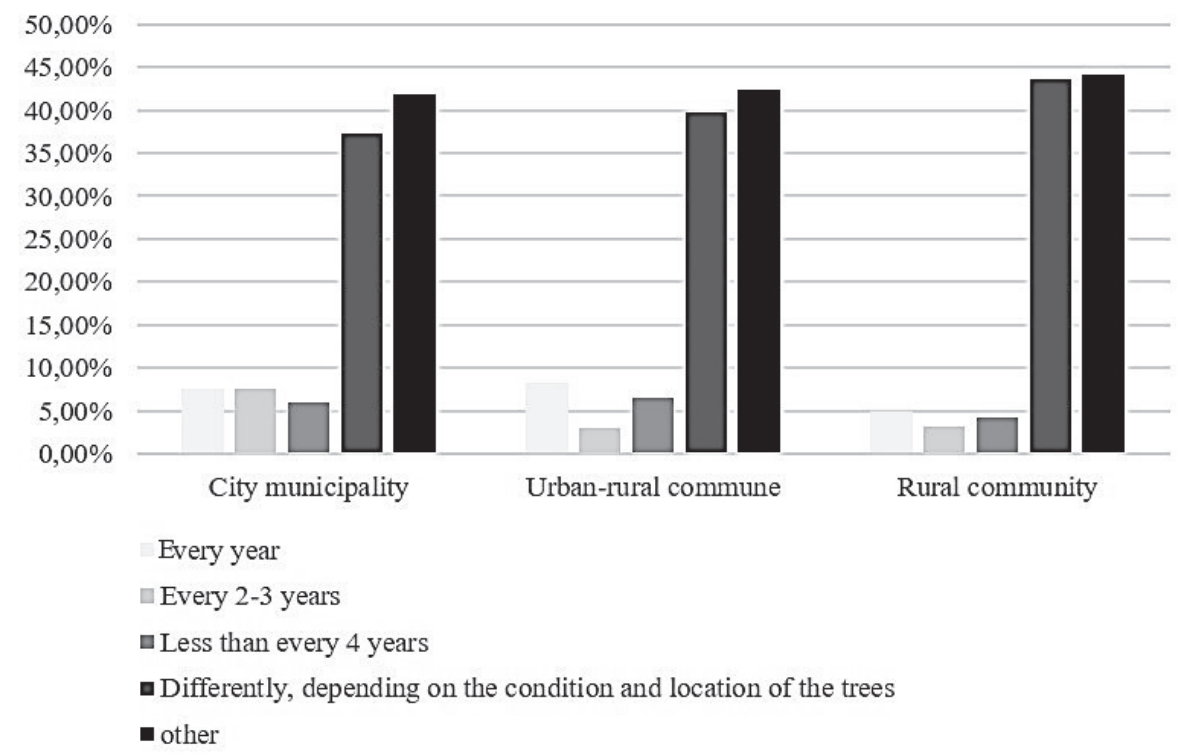

FIGURE 2. Frequency of tree control in municipalities 


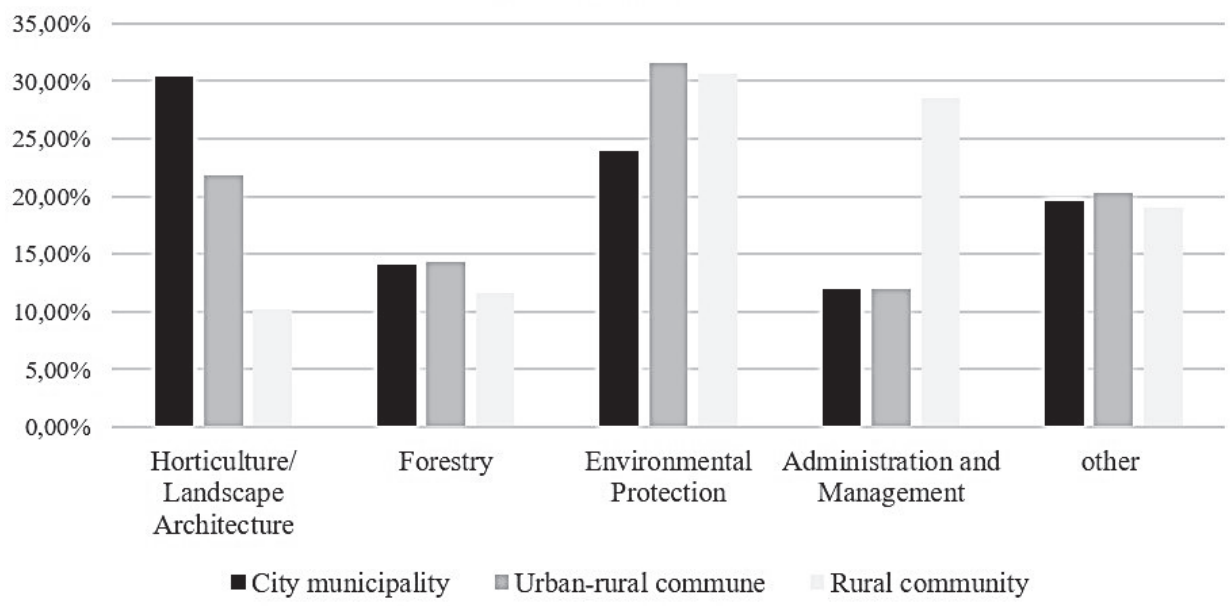

FIGURE 3. The profile of the education of tree administrators in municipalities

majority that "rather yes". Nevertheless, $40.3 \%$ of the respondents which were mainly officers of city municipalities said "no". In the case of only $29.9 \%$ of city municipalities were the inventories performed by the same person. The rotation concerning persons conducting tree inspections is $34.4 \%$ in the case of rural communities and $29.6 \%$ in the case of urban-rural communes.

It is essential to provide an objective method of trees assessment. Unfortunately, the majority of administrators assess the trees subjectively, basing on their own experience and intuition (RC 93.9\%; URC 93.5\% CM 86.6\%). The trees are very rarely examined by using technical equipment (CM 4.5\% RC 2.4\% URC 1.9\%) - Figure 4.

The accuracy level of the tree assessment in most municipalities is very general and depends on the condition of the tree (RC 82.2\%, URC 77.8\% CM 62\%). Precise measurement of all diseases, defects and tree injuries is carried out by city municipalities in $35.8 \%$ of cases, while in the rural communities only in $9.7 \%$.
In the second stage the way of risk assessment and risk identification in Poland was evaluated. In the risk management the most important aspect of improving safety is to carry on control of the effectiveness of implemented procedures and monitoring the scale of problems. This means managing the statistics concerning the number of blown down and felled trees and the occurrence of accidents/ /damages. The collected surveying data indicate a low level of the use and result implementation of this knowledge.

There were not many positive answers from the above respondents to the question "Whether tree inspections are being conducted after abnormal weather conditions (wind, black ice, flood)?". The answer: "yes, always" has been given by $29.9 \%$ city municipalities, $20.4 \%$ urban-rural communes, and only $11.3 \%$ rural communities.

Unfortunately, there is no precise criteria for "registration data concerning accidents caused by trees". The majority of respondents do not collect information about accidents caused by the blow- 


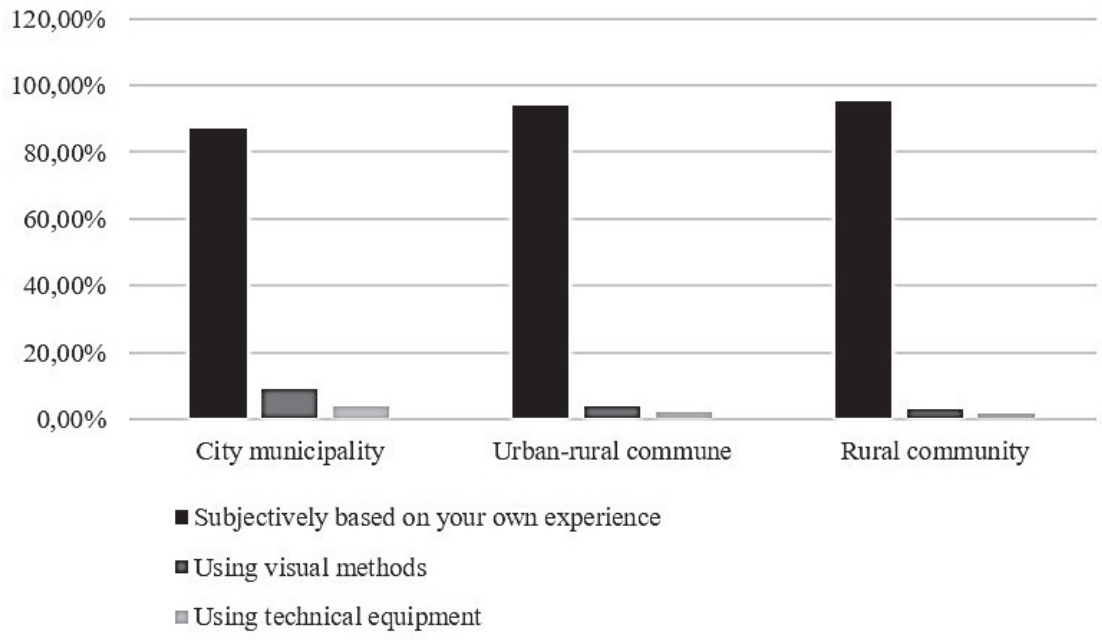

FIGURE 4. How to control and evaluate trees

ing down of trees. The biggest percentage share of communities which collect such information is formed by the city municipalities (29.9\% of respondents). Such statistics are being made by $22.2 \%$ urban - rural communes and $17 \%$ by rural communities.

The aim of the monitoring is the updating of tree resources. More than $70 \%$ of respondents said that new planting of trees was not registered (RMC 76.0\%; M $71 \%$; RC 67\%). Approximately $80 \%$ of respondents said that the removed trees were not plotted from the stock of greenery (URC 89.8\%; RC 85\%; CM 79.1\%) - Figure 5.

Further the way of risk treatment in Poland was assessed. In the case of an unacceptable risk of accident caused by trees, preventive action and action minimising the risk is rarely taken. In most cases (more than $50 \%$ ), radical measures are taken to remove a tree $(\mathrm{CM}-41.4 \%$; URC $-58.5 \%$; RC $-57.5 \%)$. However, only $30 \%$ of communities (mainly city municipality) believe that identifying trees with defects and taking corrective action (such as crown reduction) helps to reduce the impact of storms and hurricanes. Only $5 \%$ of municipalities use other measures to minimise the risk of accident caused by trees, such as: tree fences, land reorganisation, tree marking, mechanical reinforcement etc. - Figure 6.

In the US, fallen tree damage is covered by most homeowners' insurance policies. In Poland, fallen trees are a bit of an insurance grey area. Only $25 \%$ of respondents of rural communities have an insurance policy, which includes compensation for damage caused by fallen and broken trees. Half of respondents from municipalities have responded that they have such insurance policies.

Finally social consultation and communication concerning trees problem was assessed. Educational activities are also important to raise awareness on the importance of trees in the city among society. It is highly recommended to educate the users of greenery on the 


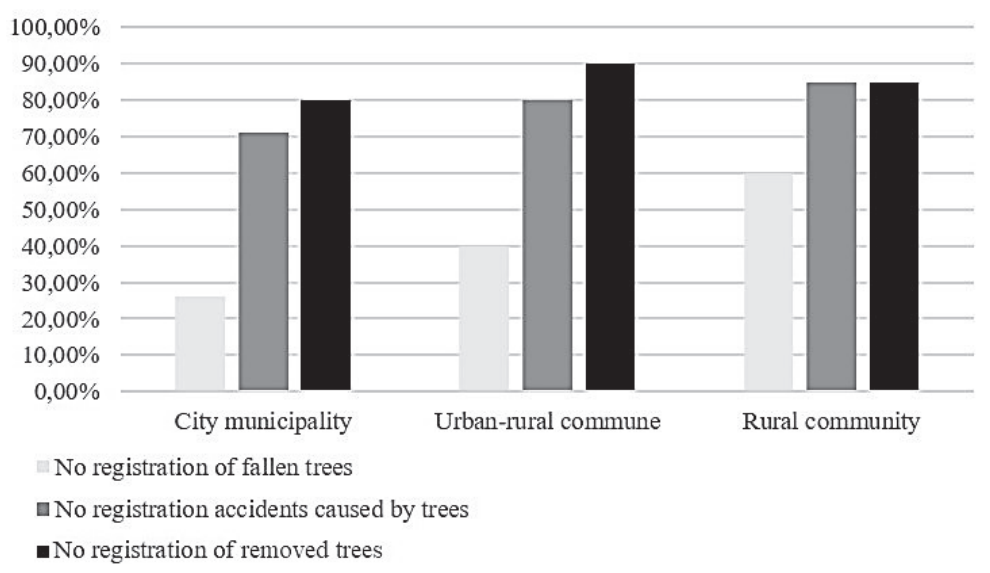

FIGURE 5. Monitoring of trees in municipalities

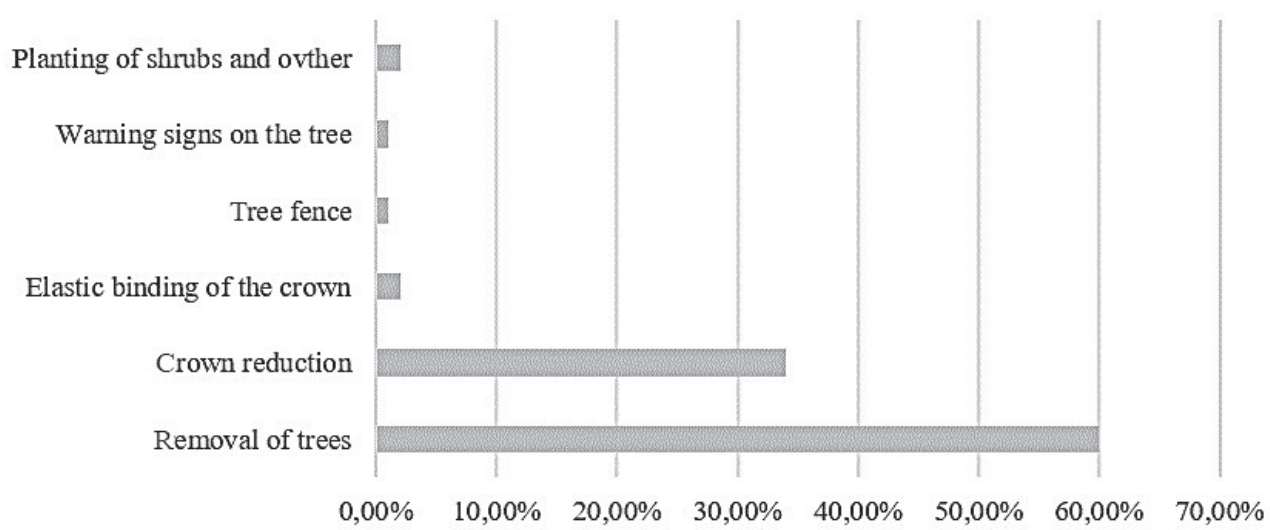

FIGURE 6. The most common procedures for minimising risk associated with trees

significance of tree protection in recreational areas. Displaying the tangible benefits of healthy, uninjured trees will limit the number of cases where trees are removed because they litter or shade an area. Respondents believe that there is a need for organised action in this domain in Poland.

The respondents described by themselves the existing risk management system as unsuccessful. Their reply to the question "What should be improved in risk management concerning trees which constitute a safety hazard?" was as follows:

- the possibility of removing trees should be more flexible (mainly rural communities (as far as 50.7\%) were for this greater freedom);

- the tree assessment methods should be improved, (it was suggested by $29.9 \%$ of respondents of city municipalities);

- the administrative procedures in issuing decisions concerning trees should be simplified and shortened; 
- the financial funds for tree maintenance and diagnosis should be increased;

- the number of employees managing the forests should be increased;

- the financial funds for tree inspector training should be increased;

- the trees' protection standards should be created before they are damaged;

- to introduce an extensive insurance system.

The risk of being struck and killed by a tree falling therefore represents an extremely small proportion of the background risk that we commonly accept in our everyday lives. However, there can be pressure to remove trees because of a perception of risk, which may be much greater than any actual risk that a tree poses. Based on the above independent data and advice, this good practice guide has adopted the 1 in 10,000 threshold of acceptable annual risk of death or significant harm from any particular tree hazard (NTSG 2011).

On average 8-14 tornadoes occur each year in Poland, of which 5-7 are weak tornadoes and 1-3 are significant tornadoes. We estimate violent tornadoes occur once every one or two decades (Taszarek and Brooks 2015). Compared with road accidents or flood disasters, accidents caused by breaking and toppling trees are very rare in Poland. The statistics of these occurrences gathered during 38 significant regional and nationwide windstorms in the years 2000-2004 prove that this is truly the case. During the 5 years in question, there were 108 reported victims of wind-toppled trees, 27 of whom died as a result of fatal collisions with the tree while 21 escaped the accident without serious injuries. By comparison, the number of road accidents in the same timeframe was 266,836 resulting in as many as 335,891 victims, including 29,007 fatalities, according to police statistics. These figures are even more interesting when you consider that falling trees caused as many deaths in five years as road accidents did in seven days (Rosłon-Szeryńska 2012).

\section{CONCLUSIONS}

Based on the survey, there is lack of standards and procedures associated with Tree Risk Management in our country. The Polish law (the nature conservation act) mentions trees which endanger the safety of devices, people or property and road, rail and shipping safety, although the removal of a tree requires notification to the proper authority without incurring any charges. However, there is the lack of a method stipulated criteria of hazard tree risk assessment, which leads to many abuses. There is also lack of detailed knowledge about accidental risk and statistics relating to the causes of weakening trees. There is no statistics of accidents caused by falling trees. Trees are assessed only occasionally, mostly in the investment process or at the special request of the owner of a property. The permanent and regular tree inspections carried out by proper units have very often a subjective character and do not allow for the current monitoring of ongoing changes in trees and their surroundings. Even in the case of stating a security threat there is rarely used the whole wide range of risk mitigation actions, limiting procedures to radical action and finally to remove the trees. 
Even if there is a regular tree inspection (mostly roadside trees) in Poland, the actions are based on the risk management system. There is a lack of setting priorities. The frequency and scope of tree control is based on arbitrary conditions. The tree assessment is very often carried out subjectively.

Therefore it is important to improve the tree management system in municipalities basing on similarly operating structures in other countries (Rosłon-Szeryńska 2013). It is necessary to develop a tree management system on the basis of the following conditions:

- In the environment protection program or other strategic documents for communes implemented on the basis of resolutions and ordinances, the standards and criteria of the tree management system should be defined.

- Tree-related risk management systems can also form part of safety strategies.

- Tree inspections should be conducted based on objective methods.

- Training for managers and owners of green areas is also highly important.

- It is extremely important to monitor the risk (collecting statistics of accidents). These measures will allow us to determine the true scale of the hazards, to raise awareness, and can contribute to cost reductions and the promotion of accident insurance, thereby increasing perceived social safety.

\section{REFERENCES}

CODER K.D. 1996: Tree risk management and hazard assessment: a general overview. The University of Georgia, Co- operative Extension Service, Forest Resources Unit Publication for 96-033.

KOESER A.K., HAUER R.J., HILLMAN A., PETERSON W. 2016: Risk and Storm Management Operations in the United States. Arborist News 25 (2): 20-23.

MATHENY N.P., CLARK J.R. 1994: A photographic guide to the evaluation of hazard trees in urban areas. International Society of Arboriculture, Savoy, II.

National Tree Safety Group 2011: Common Sense Risk Management of Trees. Forestry Commission. Retrieved from: http:// www.forestry.gov.uk/pdf/FCMS024.pdf/ \$file/FCMS024.pdf

PARLIŃSKA A. 2016: System zarządzania ryzykiem związanym $\mathrm{z}$ drzewami jako narzędzie poprawy miejskiego bezpieczeństwa publicznego. MSc thesis. SGGW, Warszawa [typecript].

ROSŁON-SZERYŃSKA E. 2012: Ocena zagrożenia bezpieczeństwa ludzi i mienia przez drzewa o osłabionej statyce. Uprawa i Ochrona Drzew 27: 45-47.

ROSŁON-SZERYŃSKA E. 2013: The protection of urban trees and the perceived safety hazard. Sustainable Development Applications (Nature in the city - solutions) 4: 52-65.

ROSŁON-SZERYŃSKA E., SIKORSKI P., ZARAŚ-JANUSZKIEWICZ E. 2014: The effectiveness of the visual method of hazard tree assessment (WID method) in the management of urban trees. Plants in Urban Areas and Landscape: 89-93. http://dx.doi.org/10.15414/2014.978805 5212623.89-93

SZCZEPANOWSKA H.B. 2001: Drzewa w mieście. Hortpress, Warszawa.

TASZAREK M., BROOKS H.E. 2015: Tornado Climatology of Poland. Am. Meteorol. Soc. 143: 702-717.

Streszczenie: Zasady planowania zarzadzania ryzykiem zwiqzanym z drzewami w Polsce. Drzewa są ważnym elementem w przestrzeni zurbanizowanej, a ich obecność w miastach przynosi wiele korzyści. Drzewa mogą jednak stanowić zagro- 
żenie dla ludzi i mienia. Ważne jest, aby oszacować ryzyko powstania wypadku oraz szkód spowodowanych wiatrołomami i wywrotami w celu ochrony bezpieczeństwa lokalnego. Ogólnym celem programu zarządzania ryzykiem związanym $\mathrm{z}$ drzewami jest zmniejszenie prawdopodobieństwa wystapienia szkody do poziomu ryzyka akceptowalnego. Systemy zarządzania ryzykiem związanym z drzewami rozwijają się szybko, szczególnie w Niemczech i Stanach Zjednoczonych. Celem niniejszych badań jest rozpoznanie, jak działa i czy istnieje system zarządzania ryzykiem obejmujący problem upadających i łamiących się drzew. Przeprowadzono sondaż w postaci ankiety elektronicznej wśród jednostek samorząu terytorialnego. Odpowiedzi uzyskano od 422 gmin o różnym charakterze: gminy miejskie $(15,9 \%$ respondentów), gminy miejsko-wiejskie $(25,6 \%$ ankietowanych) i gminy wiejskie $(58,5 \%)$. Kwestionariusz został przygotowany $\mathrm{w}$ formie 25 pytań zamkniętych i 4 pytań otwartych. Przeprowadzone badania wykazały, że choć w Polsce prowadzi się przegląd drzew zwłaszcza rosnących przy drogach i ulicach, to jednak nie obowiązują żadne standardy i procedury przebiegu tej oceny. Nie ma systemu zarządzania ryzykiem związanym z drzewami. Nie określa się priorytetów, częstotliwości i zakresu prowadzonej kontroli drzew w zależności od ich kondycji, miejsca, w którym rosna, ani poziomu zagrożenia, ja- kie stwarzają. W efekcie badań przedstawiono wskazania do wprowadzenia systemu zarządzania ryzykiem związanym z drzewami. Wytyczne i wskazania do prowadzenia monitoringu drzew powinny być zawarte $\mathrm{w}$ programach ochrony środowiska dla gmin i administratorów terenów zieleni lub w innych dokumentach zawierających plany zakładania i utrzymania zadrzewień wprowadzanych w życie na mocy uchwał i zarządzeń. System zarzadzania ryzykiem związanym z drzewami może być także składnikiem strategii bezpieczeństwa.

Slowa kluczowe: gospodarowanie drzewostanem, ryzyko związane z drzewami, zarządzanie ryzykiem związanym $z$ drzewami

MS received: 01.10.2017

MS accepted: 10.07.2018

\section{Authors' address:}

Edyta Rosłon-Szeryńska

Katedra Ochrony Środowiska

Wydział Ogrodnictwa, Biotechnologii

i Architektury Krajobrazu

Szkoła Główna Gospodarstwa Wiejskiego

w Warszawie

ul. Nowoursynowska 166, 02-787 Warszawa

e-mail: edyta_rosłon_szerynska@sggw.pl 